\title{
Insecurity and Patterns of Foreign Direct Investment in Nigeria (1999-2014)
}

\author{
Adebukola Olubunmi Ayoola \\ Department of History and International Studies, Faculty of Humanities, Bowen University, Iwo, Nigeria \\ Email: adebukola.ayoola@bowen.edu.ng,bukyayoola@yahoo.com
}

How to cite this paper: Ayoola, A. O. (2022). Insecurity and Patterns of Foreign Direct Investment in Nigeria (1999-2014). Open Journal of Political Science, 12, 28-45. https://doi.org/10.4236/ojps.2022.121003

Received: January 14, 2021

Accepted: January 8, 2022

Published: January 11, 2022

Copyright $\odot 2022$ by author(s) and Scientific Research Publishing Inc. This work is licensed under the Creative Commons Attribution International License (CC BY 4.0).

http://creativecommons.org/licenses/by/4.0/

\begin{abstract}
This study examined the nature and trend of insecurity and patterns of Foreign Direct Investment (FDI) in Nigeria from 1999-2014 with a view to provide information on how insecurity affects the patterns of FDI in Nigeria. The study employed both primary and secondary data. Primary data were sourced through in-depth interviews conducted on purposively selected respondents from Ministry, Departments and Agencies (MDAs) of government who are directly involved in handling issues of security and FDI in the country; economic attaché of some selected embassies; foreign business organisations in the country and the academia with interest on FDI and security issues. Secondary data were sourced from academic journals, government publications, newspapers and magazines on variables such as FDI and insecurity. The study adopted the theoretical framework of liberal transnationalism of political economy perspective. Data were analysed using qualitative and descriptive methods. The result revealed that the nature and trend of insecurity negatively impacted on the patterns of FDI in Nigeria both in the oil and non-oil sector within the period under studied.
\end{abstract}

\section{Keywords}

Insecurity, FDI, Trend and Patterns

\section{Introduction}

Foreign Direct Investment (FDI) plays a major role in the economic development of emerging markets. This is important, because FDI provides capital to finance domestic projects as well as expertise to undertake such projects. The competition for getting FDI inflow has become stiffer as both advanced countries and developing countries are all showing growing interest in attracting FDI. The importance of FDI to a developing or less-developed country has been em- 
phasized by different people. This has to do with its role of improved technology, efficiency and productivity that can promote economic growth (Lim, 2001). Be that as it may, the potential contributions of FDI depend strictly on the circumstances in the recipient country. Certain conditions of the host country are necessary to facilitate the spill-over effects. The extent to which FDI contributes to growth depends on the economic and social conditions of a country. This refers to the quality of environment of the recipient country (Buckley, Clegg, Wang, \& Cross, 2002).

Investors hold the view that political stability in the host country is important in considering their choice of investment locations and deciding the amount and volume of investment in that country. Enders and Sandler (1993) point out that political instability and social unrest have negative effect on FDI inflows, as insecurity in any form reduces the chances of a country being selected as an investment location. These social unrest and political instability can also dictate the patterns of investments within the host country. The patterns can reflect a spread across the host country or cluster of investment in a particular area. This also depends on the nature of the geographical environment and how conducive the various investment locations are within the country.

Insecurity constitutes all forms of violent activities in a country. These could be political, economic or social violence as long as such action disrupts the peace and stability of the society thereby altering the normal order of living of the people. In addition, it is the total breakdown of law and order in a country which alters the normal course of life of the people and even that of the government resulting in social disorder, wanton destruction of lives and property. Insecurity in Nigeria has to do with the various situations of social unrests or violent uprisings in the country at one time or the other. It also concerns how these have impacted on the social, economic and political development of the nation. Nigeria since independence, has witnessed series of social and violent unrest at different times and in different forms. Some are economic based, political and offshoot of ethnic and religious crises. There was the Maitatsine religious disturbances in Kano and Maiduguri in the early 1980s, Jimeta Yola religious disturbances in 1984, Zango Kataf, Bulumkutu Christian-Muslim riots, just to mention few. These are offshoots of primary causes of insecurity in the country, such as poverty, inequality, unemployment, illiteracy, deprivation, corruption, religious manipulations and others.

The spate of ethno-religious conflicts, socio-economic and political violence in Nigeria has increased with return to civil rule in 1999. The frequency of such occurrences is as a result of the freedom provided under the democratic rule. Of major concern is the increase in sophistication of weapons and attacks on the people leading to destruction of lives and property, all of which have heightened the insecurity situation of the country. There has been militancy in the Niger Delta region, ethnic violence, and Boko Haram insurgency in the North-East region. In addition, the Boko Haram group has transformed in size, nature and 
modes of operation from one time to the other. It has developed from Islamic organisations to Jihadist terror groups and lately become insurgents. They take over towns for themselves and set their flags as symbol of authority over the areas captured to questions the authority of the legitimate government of the country.

Nigeria recorded 1094 violent attacks between 2000 and 2012, claiming over 20,000 lives, as a result of all these violent disturbances in the country (Global Terrorism Database, 2014). In 2014 alone, over 3500 persons were reported dead, with refugee camps of Internally Displaced Persons (IDPs) in almost everywhere as the Boko Haram terrorist groups advanced in their bid to seize villages and towns in the North-East. Thousands of people were reportedly kidnapped, including women and children.

The increase in the spate of insecurity in Nigeria is a major concern for both government and the governed while it succeeded in drawing international attention to the country. Counting the cost of various security challenges featuring in the country, the statistics could be discouraging for any would-be investor as they portend danger. These would translate to high cost of risk management, increased spending on security in terms of diversion of scarce capital for the procurement of hi-tech equipment for the purpose of combating insecurity. The primary objective of every investor is to maximise profit and this may not be achievable if so much capital is invested to ensure security of lives and property. Therefore, this study examined the trend of insecurity and patterns of foreign investment in Nigeria from 1999 to 2014.

\section{Theoretical Framework and Literature Review}

\subsection{Theoretical Framework}

In analysing the importance of FDI to economic development of any country especially the less-developed and developing nation like Nigeria and the much needed level playing ground and conducive environment for foreign investors to operate, this study focused on the liberal transnationalism theory of the political economy perspective. Although there are other relevant theories analysing acts of terrorism and FDI separately but they are limited because such could not address the nexus between the two variables. The liberal transnationalism theory of political economy perspective provided a suitable platform for analysis in this study it emphasises the importance of FDI as portrayed by the multinational corporations, the necessity of free movement of goods and services across borders and the role of the state to provide a conducive environment for individual to reach his/her goal unhindered. This is based on classical economic liberalism that is rooted in reactions to important trends in Europe in the $17^{\text {th }}$ and $18^{\text {th }}$ centuries. The idea of economic liberalism condemns government interference in the market because such interference could bring harm to the society. According to Viotti and Kauppi (2012), the term "Liberalism" means liberty under the law. It focuses on the human nature that is competitive in a constructive way 
and is guided by reasons and not emotions.

Liberalism is a tradition of political thought composed of a set of practical goals and ideals. According to classical liberal theorists, the individual is the most important unit of analysis and the claimant of rights. The state is therefore expected only to play a minimal role in a classical liberal society, acting as arbiter in disputes between individuals and ensuring the maintenance of conditions under which individuals can enjoy their rights to the fullest. The theory's preference for the state's role is limited to maintaining a stable political, social and economic environment within which individuals can interact and pursue their chosen ends. That means it is the duty of the state to ensure all-round conducive environment for all to operate and pursue their individual goals and objectives without any interference. The liberal concerns for individuals were reinforced by Adam Smith's and David Ricardo's works in economics. They emphasise the important role of the individual entrepreneur who should be relatively unconstrained by the state. Liberalism emphasises individual's role in all aspects of life and thought—scientific, political, economic, social and religious (Dunning, 1992; Waltz, 1979).

Liberal transnationalism is about free market enterprise across national boundaries with particular attention on the increasing role of multinational corporations abroad and the challenge they posed to the sovereign prerogatives of states as they transited across national boundaries in the daily conduct of their business transactions. Transnational was used to describe either an actor (Multinational Corporation) or a pattern of behaviour (MNCs act transnationally). Viotti and Kauppi (2012) posit that the focus was on studying these actors, their interactions and the coalitions they form across state boundaries that involved diverse non-governmental actors such as MNCs, banks, churches and eventually human rights, environmental and terror or criminal networks. Transnationalism also focuses on the links between trans-governmental agencies at the level of bureaucracies as a challenge to the state as a unitary actor. Links or coalitions between non-governmental organisations and trans-governmental actors also became very important. This, however, does not suggest a leakage in state sovereignty or rendered it irrelevant. Rather, the role of the state is recognised as germane to the survival and success of the links or coalitions of trans-governmental actors and to achieve their set goals and objectives. This role the state performs by ensuring a politically, socially, and economically conducive environment for the TNCs/MNCs to operate to the maximum capacity.

This brought to the fore the interdependency between the state and the transnational actors. As Nye and Keohane (1998) put it, interdependence is all about mutual dependence resulting from the types of international transactions catalogued by transnationalists, that is, flows of money, goods, services, people, communications and so on. This is characterised by reciprocal effects among countries or among actors and different countries. Marfleet (2006) says liberal transnationalism has become strengthened by globalisation as the world integra- 
tion acts as a driver of increased prosperity and harmony. The liberating powers of the market are bringing benefits for all as there is a general advancement of economy and society and reduction of political tension and conflict. The intensification of global relations in the respective realms of commerce, communications, technology, economic production and finance has certainly enabled some non-state actors to maximise their profit-making potentials and reach previously inaccessible markets.

It is important to state here that the activities of MNCs as transnational actors have become strengthened by economic liberalism which compels the state to provide a stable/free market enterprise and politically, socially and economically conducive environment for them to operate. In the same vein, it has enhanced other transnational actors (such as terrorists, criminals or insurgency groups) to form coalitions and links across borders, whose activities now threaten the operations and survivals of MNCs as agents of FDI in their host countries especially in the less-developed and developing countries bedevilled by various security challenges like ethno-religious violence, militancy, terrorism and insurgency as the case is in Nigeria.

\subsection{Insecurity and Foreign Direct Investment}

It is natural to express fear and anxiety that insecurity would have a negative impact on FDI flow to any affected country. Empirical studies dictate that the loss of foreign investors' confidence occasioned by security challenges would prompt large outflows of capital in affected countries. Also, the fact that a country is branded a security risk because of high level of insecurity features like militancy, ethno-religious violence, terrorism and insurgency, would make it less attractive to FDI. While some studies have demonstrated that this is sometimes the case, others have proved that foreign investors' sentiment is not always dictated by common sense. The lure of profit and desire to establish trade partnerships is often a stronger motivational force than perceived political and security risk as disincentive to invest.

According to Wagner (2006), in spite of the fact that the growth of global terrorism is on the minds of some corporate decision makers when contemplating whether to or not invest abroad, it has not prevented many of them from investing in the post-9/11 developing world. Supporting his view with the 2005 UNCTAD's World Investment Report, FDI flows to the developing world surged by 200 percent between 2000 and 2004, up from 18 percent to 36 percent of global FDI. At the same time, FDI flows to developed countries decreased by 27 percent from 81 percent to 59 percent of global FDI. In every category of developed countries cited, as Wagner observes, the inward FDI trend is down significantly while the inward FDI trend is sharply higher in every developing country category as he also notes that the vast majority of militant activities, terrorist attacks and ethno-religious violence take place in developing countries.

Some other literature brought to the fore questions about the determinants of 
FDI location. According to these authors, main determinants of FDI location includes, agglomeration effects, infrastructure effects, factor cost effects and market access effect (Coughlin et al., 1991; Friedman et al., 1992; Chen, 1996; Cheng \& Kwan, 2000). Agglomeration effects might be as a result of positive linkages among project and a major incentive is spill-over effects created by research and development as well as confidence and the possibility that firms cluster. The third incentive arises from the supply of, and the demand for intermediate goods. However, Chen (1996), Cheng and Kwan (2000) observe that most of developing countries have succeeded in attracting FDI through special economic policies like establishment of special economic zones and construction of new roads, like Tinapa in Calabar and China Town in Lagos. This infrastructure, according to them, help FDI investors to decrease set up cost of new local establishments in host countries. All these factors couple with the market size affect inflow of FDI more often, that incidents of terrorism and other forms of security challenges may be considered as secondary by investors whose primary objective is to maximize profit.

On the other hand, several economic analyses proved that conflicts, such as terrorist incidents, ethno-religious violence, militancy and insurgency increase the level of insecurity and affect a country on the national level. Having studied the negative effects of insecurity on Gross Domestic Product (GDP) of 177 countries from 1968 to 2000, Blomberg et al. (2004) observe that both internal and external conflicts have a negative effect on FDI. They found that all forms of conflict had a negative effect on GDP. Crain and Grain (2006) go further while they analyse the consequences of conflict on the macroeconomic level and restricted the analysis to international terrorist incidents. They expanded the research to look at terrorism's effect on GDP, GDP growth, investment, consumer expenditure and tourism for 146 countries from 1968 to 2002. The observation results show that terrorism has a negative effect on all the variables tested.

In a related study, Enders and Sandler (1996) look at the effects of terrorism on net foreign direct investment (NFDI) using time-series analysis to observe the effect of terrorism on NFDI in Spain and Greece between 1968 and 1991. They found that in Spain, an average amount of terrorist incidents in a year reduced NFDI by $13.5 \%$ while an average amount of terrorism over a year in Greece reduced NFDI by 11.9\%. In their findings, Enders and Sandler (1996) observe that terrorist incidents took 3 years to affect FDI where attacks have to occur consistently over the period observed, attacks must target foreign commercial interests, and the country must be small. They believe that large countries are more resilient to the effects of a terrorist incident. Resilience is attributed to the diversity from which large countries obtain their foreign investment inflows as well as having more resources to absorb the risks associated with insecurity. Martins (2007) carried out an empirical analysis across 96 countries from 1999 to 2003. His observation supports that of Enders and Sandler that there is a statistically significant negative effect on FDI when terrorist incidents 
were consistent for a period of three years. His study reveals that terrorist incidents which lagged for one year had no significant effect on FDI. In the countries observed within that period, an increase of 10 percent of domestic terrorist incidents decreased FDI by 1.22 percent annually which, according to him, can have economically significant impacts on economic growth. He concludes that terrorism remains an important factor that investors take into account when analysing the risk factor that a potential investment may have.

In summary, all forms of insecurity are threats to the FDI inflow to Nigeria. Therefore, this study examined and evaluated the impact of insecurity on patterns of FDI in the country and the effects on the economy.

\section{Methodology}

This study employed primary and secondary sources of data. Primary data was sourced through in-depth interview conducted on respondents from selected MDAs, UNO, embassies/high commissions, academia and foreign business organisations that made up the sampled population. The population comprised Nigeria Army, Nigeria Police Force, Nigeria Intelligence Agency, the National Assembly, Ministry of Trade and Investments and Ministry of Foreign Affairs, Nigeria Investment Promotion Council and National Bureau of Statistics. Others included United Nations Office and embassies/high commissions of the United States of America, Britain, France, China, Germany, Japan, Indian and South Africa. This was also extended to the academia and six foreign business organisations in Nigeria. They were Chevron Nigeria Limited, Julius Berger Construction Company, Nestle Nigeria Plc, Shoprite Nigeria Plc, Peugeot Automobile Nigeria (PAN) and Mobile Telecommunication Network (MTN) Nigeria Plc. The research design was based primarily on one-on-one discussion with each of the 36 purposively chosen interview respondents. This ensured availability of time and ample opportunity for detailed and in-depth discussion that generated qualitative data for this study. Data collected were analysed using simple qualitative and descriptive methods. Descriptive method was used to show frequencies, percentages and rating indices of respondents. These were presented in tables in the analysis.

\section{Analysis and Discussion on Trend of Insecurity and Patterns of FDI}

The analyses of data collected for this study presented the views of respondents on the nature and dynamics of insecurity in Nigeria as being perpetrated by different violent groups with particular references to Niger Delta militants in the SouthSouth and Fulani herdsmen assailants and Boko Haram terrorists/insurgents in the North-East. The nature and dynamic dealt with the modes of operation of these group, the various changes in their strategies from one time to other, the increase, modifications and sophistication of their weaponry and the intensity of attacks leading to increase in fatalities and wanton destruction of property. It 
also presented the analysis showing trend and patterns of foreign direct investment in Nigeria between 1999 and 2014.

Findings revealed that the nature and dynamics of insecurity expanded at a fast rate within the specified period of 1999 to 2014 and these are rooted in the ideologies of these groups and the metamorphosis/evolution of their modes of operation. In the South-South, militancy evolved through different stages. It started as fragments of tribal/ethnic group to pressure groups making economic demands from the government but the activities of the groups later became violent in that they resulted in the use of dangerous weapons like arms and ammunition to drive home their demands. Their operations started with peaceful protest to disruptions of oil production, pipelines vandalism, to hostage taking, kidnappings and engaged in arms face-off with government security agents in their bid to take over the creeks and shut down oil production in the Niger Delta until the government responded to the demand. In the North-East, the Boko Haram groups started out as religious fundamentalists but they continued to evolve to Islamic Jihadist/terrorists and later insurgents. They succeeded in taking over 14 local governments in the North-East which they attempted to subject to their own government and rule by Islamic injunctions. In fact, they had already set their flags as symbol of authority and autonomy before the military crackdown on them led to the recovery of the territories. The dynamism also reflected in their modes of operations which were becoming swifter and faster, leading to more fatalities as the year progressed. There were improvement in the lethargy of weapons from knives and machetes at their early stage to use of guns like AK47, assault rifles, to detonations of improvised explosive devices (IED), vehicle-borne improvised device (VBIED) before they graduated to using male and female suicide bombers. The weaponry was becoming more and more sophisticated as the year progressed. The patterns of investment on the other hand reflected a fluctuation as the year progressed within the period of study. It was a bit steady from 1999 to 2005. Investment in the oil sector recorded a decrease of $20 \%$ between 2006 and 2008 due to the intensity of militant activities in the $\mathrm{Ni}$ ger Delta region at the time. There was also drop in oil production from 3.2 million barrels per day to $1.2 \mathrm{mbpd}$ as a result of the increase in militant activities like sabotage, oil bunkering, hostage takings and kidnapping. The number of persons reportedly kidnapped from 2006 to 2009 is 512.

The question of the nature and dynamics of insecurity in Nigeria was raised in the interview with all the respondents and they were all quite explicit on the danger of increased sophistication weaponry and metamorphosis in the mode of operations among the perpetrators of insecurity in Nigeria. All the respondents were unequivocal on the multifaceted nature of insecurity ranging from militancy to insurgency, ethnic violence, herdsmen encroachments, religious uprisings, vandalism, kidnapping, armed robbery and more. One of the respondents, a deputy director of Army Public Relations when interviewed on the nature of insecurity said the weapons of some of the insurgents are more powerful and 
sophisticated than that of the military, such that some of the deployed forces had to retreat at some instances. He went further that, the increase in the rate and spate of attacks especially with the introduction of suicide bombing in 2011 and calculated simultaneous attacks have resulted in high increase of fatalities. These acts he pointed out have rendered the security operatives incapacitated.

All the seven respondents interviewed on security issues believed that the dynamics of insecurity is evidenced in their methods or intensity. It is both spontaneous and planned and usually takes place simultaneously in different locations. The targeted locations for the acts by the insurgents are capitals and remote areas where security agencies exercise little control. A further investigation showed that majority of the violence occurred at states sharing borders with other countries and states perceived to be marginalised by the Federal Government. This group of respondents comprised officials of security agencies and the academia that were purposively selected for this study. They all agreed that between 2009 and 2014, there has been a dramatic twist in the nature and dynamics of insecurity in Nigeria. These were measured by the sophistication in the weaponry, the rate and intensity of attacks and high rates of casualties. One of them a professor of peace and security studies who has worked extensively in this area posits that Nigeria faces a combination of multifaceted security challenges each of which on its own is profoundly destabilising. These include insurgency in the north, militancy in the Niger Delta, kidnapping and ritual killings in the East, West and Southern parts, cattle rustling, ethnic and religious violence in almost every part of the country.

According to these security experts, the nature of insecurity has become more sophisticated to the extent that it has moved away from isolated cases of kidnapping for ransoms, hostage taking, and pipelines vandalism to calculated ones aimed primarily at the destruction of high-profile soft targets in an attempt to cause maximum damage.

A number of aspects of the multifaceted nature of insecurity in Nigeria as generally expressed by the respondents include the dynamism in the sense of its frequency, randomness, guerrilla tactics, intensity and deadliness of the attacks. Also, Nigerian institutions like government buildings, schools, security installations, oil pipelines, markets shopping malls and motor parks have become the prime targets to ensure maximum casualties.

Table 1 presented data on attacks and fatalities which further lent credence to the deadly nature of insecurity in Nigeria between 1999 and 2014. Data showed that between 1999 when Nigeria returned to civil rule and 2004, the rate of fatalities was high with the period witnessing high point of militancy in the Niger Delta. In addition to this were political tensions and the 2003 post-general election violence, activities of tribal groups like Egbesu boys, Movement for the Actualisation of Biafra, Oodua Peoples' Congress, Fulani cattle rustlers attacks, religious violence and other political and economic agitations from different groups of people within the country. There were communal clashes like that of 
Ife/Modakeke, Ijaw/Ishekiri, chieftaincy crises, leadership tussle by drivers' unions (NURTW, RTEAN) and other forms of crises within the period that were responsible for the high record of fatalities. In fact, the view was expressed that with the end of autocratic rule and emergence of democratically elected government, there arose more vocal agitations resulting in communal clashes, tribal and ethnic violence and more. There was a decrease in the fatalities between 2005 and 2008 which showed some forms of socio-political stability in the country. This was the period that the government embarked on amnesty programmes for the militants with the appeal to them to drop their weapons and embrace peace. The programme achieved result to a large extent and there was relative peace in the country. Also, it was a period the new democratic government was beginning to gain stability and peoples' confidence in the democratic process after the third election in the fourth republic. By 2009, there was an upward swing in the rate of fatalities recorded up till 2014. 2009 witnessed the coming into prominence of religious fundamentalism led by Muhammed Yusuf. The group known as Yusufiyyah later transformed to Boko Haram. The activities of the group received a major crackdown from the government that led to the death of their leader, Yusuf and many of his followers at the time. The military crackdown on the group also received counter-attacks from aggrieved members against the state. There were also many other aggrieved groups in some other parts of the country during the period. There was a slight drop in fatalities recorded in 2010 but towards the end of the year, it continued to maintain an increase until 2014. The period also witnessed political crisis, pre and post-election violence of 2011 general elections in the country. There was a re-emergence of religious fanaticism (Boko Haram) and the group's metamorphosis both in nature, mode of operations and changes in the sophistication of weapons used. 2014 was spectacular considering that the highest number of fatalities recorded in the year, a number put at 11,529 . The year witnessed a new turn in the increase the use of male and female suicide bombers and simultaneous attacks aimed primarily at high-profile soft targets in an attempt to cause maximum damage.

The above analysis gave credence to the nature and dynamics of insecurity in terms of sophistication of weapons of attacks and alarming rates of fatalities. This is presented in Table 1 below.

Table 1. Insecurity attacks and reported fatalities in Nigeria between 1999 and 2014.

\begin{tabular}{cc}
\hline YEAR & FATALITIES \\
\hline 1999 & 1791 \\
2000 & 2554 \\
2001 & 2144 \\
2002 & 785 \\
2003 & 954 \\
\hline
\end{tabular}




\section{Continued}

\begin{tabular}{lc}
2004 & 2119 \\
2005 & 91 \\
2006 & 66 \\
2007 & 270 \\
2008 & 995 \\
2009 & 2101 \\
2010 & 1983 \\
2011 & 1963 \\
2012 & 2986 \\
2013 & 4714 \\
2014 & 11,529 \\
\hline
\end{tabular}

Source: Armed Conflicts Locations and Event Data, 2015.

\section{Patterns of Foreign Direct Investment in Nigeria from 1999 to 2014}

Based on the responses of interview respondents purposively selected for this work, the patterns of investment reflected a fluctuation as the year progressed within the period of study. From 1999 to 2005, there was a steady growth in the patterns of investment in Nigeria both in the oil and non-oil sectors of the economy. According to the explanation of one of the respondents who is an expert in the oil industry, investment in the oil sector recorded a decrease of $20 \%$ between 2006 and 2008 due to the intensity of militant activities in the Niger Delta region. This led to a drop in oil production from 3.2 million barrels per day to $1.2 \mathrm{mbpd}$ as a result of the increase in militant activities like sabotage, oil bunkering, hostage taking and kidnapping. The years 2009 to 2011 recorded a steady increase that brought oil production back to $2.31 \mathrm{mbpd}$ in 2012, but there was another decrease in 2013 with production dropping to $2.21 \mathrm{mbpd}$. All the respondents from NBS, NIPC and the industry agreed that oil production experienced a continuous drop because of supply disruption arising from illegal oil bunkering, pipelines vandalism, renewed militant activities like kidnapping and hostage taking. Added to these was weak investment in exploration and exploitation of oil and gas as there was no new find in 2013 due to non-passage of Petroleum Industry Bill. Giving an insight, the respondent from the industry posited that earlier passage of PIB would have boosted investors' confidence to explore new opportunities in the sector. The trend however continued to year 2014.

On the other hand, data analysis revealed that investment in non-oil looked promising even though it contributed little percentage to the Gross Domestic Product. It maintained a steady increase from 1999 to 2014 . However, issues of insecurity in the North and other part of the country with security-risk affected the spread of investment in non-oil sector. This was concentrated in the less-risky 
zone such as South-West and South-East. According to the respondents from NBS, Nigeria's GDP could have benefited more from this sector to make up for the decrease in oil sector if issues of insecurity had not limited the spread of investment to only those areas considered as safe enough for the investments. This was evident in the responses of investment experts from the academia and respondents from the selected foreign business organisation for this study. Previous attempts to spread to the north and Niger Delta were regretted as some suffered attacks from insurgents leading to loss of lives and property. Nevertheless, non-oil investment contributed more to GDP than oil sector from 2011 to 2013 as shown in Table 2 below. While non-oil recorded 5.4\% in 2011, 8.3\% in 2012 and 7.8\% in 2013, oil sector recorded $3.4 \%,-2.3 \%$ and $5.3 \%$ respectively.

The views of interview respondents from the Ministries, Departments and Agencies of the government handling the issues of investments in Nigeria were a bit different from the above submission. These officials of Ministry of Trade and Investment, Nigeria Investment Promotion Council and National Bureau of Statistics generally agreed that the inflow of foreign direct investment into Nigeria has been on the increase despite the multifaceted security challenges facing the country. All the three respondents expressed the same view that the efforts of the government in driving foreign direct investments have continued to yield positive result in spite of the incessant security challenges in the country. In the views of respondents from the Ministry and NIPC, the increase is not unconnected with the expanse oil resources and other natural/material resources available which are in quantum in Nigeria. Still speaking on the same issue, they emphasised on stability of government since return to democracy in 1999, favourable government policies and regulatory guidelines for FDI in the country. These they described as 'investors-friendly' policies coupled with large population which translate to large market, among others as factors responsible for the upward trend of FDI in the country.

One of the MDAs' respondents however said that a deeper look into FDI in the tourism sector shower that it has been adversely affected by insecurity. $\mathrm{He}$ maintained that the sector recorded a decrease due to the fact that some countries like Britain, USA, and Italy had issued warnings to their citizens who wished to visit Nigeria to be wary of insecurity in the country. In addition, the three of them agreed with the fact that investment in other non-oil sectors are concentrated more in less insecurity-prone areas whereas such could have been

Table 2. The percentage contributions of oil and non-oil sectors to GDP from 2011 to 2013.

\begin{tabular}{ccc}
\hline YEAR & OIL SECTOR & NON-OIL SECTOR \\
\hline 2011 & 3.4 & 5.4 \\
2012 & -2.3 & 8.5 \\
2013 & 5.3 & 7.8 \\
\hline
\end{tabular}

Source: Field Work, 2015. 
spread to those areas experiencing security challenges like the North-East especially. According to the NIPC official, the North-East has not been really attracting FDI due to limited natural resources and raw materials, just as the high level of insecurity in the region has worsened the situation. Putting it in a better perspective, one of the respondents has this to say:

The FDI chances in the North-East as of now are below 5\%. This is because some of the few companies with production outlet, warehouse and installations suffered major terror attacks and losses of personnel and property. These were more prominent in telecommunications, constructions and retail companies some of whom have been forced to close shop while other in telecommunications and retails now operate from outside the region to provide skeletal services at exorbitant rate.

Overall, the 36 respondents agreed that security challenges hampered economic growth and development in Nigeria.

For the six selected multinational companies in Nigeria, their patterns of investment were dictated more by the kind of services they rendered or in their production of goods and services.

In this study, Chevron Nigeria represents the oil sector. As a multinational oil company, its operations have been restricted to the Niger Delta region. It carries out exploration and exploitation activities both in the upstream and downstream sectors. The corporate headquarters of the company is Victoria Island Lagos while the production headquarters is situated in Escravor, Delta State. The company's production and operations have been severally disrupted by the militant activities characterised by hostage taking, kidnapping, oil theft, and pipeline vandalism. Sharing his view, a Director of Operations in the company puts the scenario thus:

Words could not really describe or quantify the loss of the company resulting from militancy in this area. How would you explain the kidnapping of a three year old who, was made to suffer emotionally and starved to death just because her father works in an oil company. Should I begin to mention the several numbers of expatriates that died in the custody of these militants? This is not limited to Chevron but other oil companies in this region also suffer the same fate. We have all suffered loss of barrels of crude that have wasted or stolen due to bunkering pipelines vandalism? The list of woes and trauma is actually endless.

According to this respondent, the level of insecurity created by activities of militants in the area actually affected the production capacity of all the oil company operating in the region. More often than not, they work in an atmosphere of fear or say "climate of fear because you are going to the rig with the awareness of your likely being attacked". Apart from the drop in production activities of these companies, he said the oil companies operating in the region have not exploited new finds from 2013 till date. This was as a result of these militant activi- 
ties coupled with the glut in the market and the non-passage of Petroleum Industry Bill.

Shoprite Nigeria is a subsidiary of the Shoprite Group of companies. The South African retail outlet represents the retail sector of foreign investment in Nigeria. The company was rated as the number one retailer in Africa and the Middle-East by Deloitte Global Powers of Retailing survey, 2015. This was as a result of its wide coverage in the entire continent with 1751 corporate and 360 franchise outlets in 15 countries in Africa and Indian Ocean Islands. Shoprite made its entrance to Nigeria in 2005 with its first outlet in Victoria Island Lagos. According to one of its Managers who is in charge of Operations at the Cocoa Mall outlet, Dugbe, Ibadan, Oyo State, the company has expanded in Nigeria with additional 12 outlets even though the coverage is more extensive in the South-West. Below is Table 3 showing the company's spread and pattern of investment across Nigeria.

Table 3 indicated that there are two outlets in Ibadan South-West, one in Warri, South-East, one in Kano, North-West, one in Kwara, North-Central, two in Abuja and the remaining six outlets are clustered in Lagos State. The respondent from the company said Warri outlet was opened in 2014, and propositions for Asaba and Onitsha outlets are in the pipeline with preliminary security investigations on-going. The company was hoping to open to customers in 2015. Kano outlet was opened in 2013 with a proposal for Kaduna to take effect in 2014. However, Kano outlet suffered a major bomber attack in 2014 with a suicide bomber trying to gain entrance, but the bomb exploded right in front of the building before he could enter the shopping mall. There was no loss of life, but the outlet was closed down for renovation and this incident stalled the proposed Kaduna outlet. This was a major setback for the company whose desire is to spread across the entire region of the country considering the market as shown in the feasibility studies. Security reports in some of the regions, especially the South-South and North-East in particular, are major constraints.

Table 3. Spread of Shoprite Retail Outlets in Nigeria.

\begin{tabular}{|c|c|c|c|c|c|}
\hline South-South & South-East & South-West & North-Central & North-West & North-East \\
\hline & \multirow[t]{2}{*}{ Warri, Delta state } & \multirow[t]{2}{*}{ Surulere, Lagos state } & \multirow[t]{2}{*}{ Palms Ilorin, Kwara state } & ${ }^{* *}$ Ado Bayero & \\
\hline & & & & Mall, Kano & \\
\hline & ${ }^{\star}$ Asaba, Delta state & Ikeja City Mall, Lagos & Grand Towers, Abuja & ${ }^{\star}$ Kaduna & \\
\hline & \multirow[t]{6}{*}{${ }^{\star}$ Enugu, Enugu state } & \multirow[t]{2}{*}{ The Palms, Victoria Island, Lagos } & Silverbird Entertainment & & \\
\hline & & & Center, Abuja & & \\
\hline & & Mall Park, Apapa, Lagos & & & \\
\hline & & Festival Mall, Festac, Lagos & & & \\
\hline & & Ibadan Mall, Ring Road, Oyo state & & & \\
\hline & & Cocoa Mall, Dugbe, Ibadan, Oyo state & & & \\
\hline
\end{tabular}

Source: Field work, 2015. ${ }^{\star}$ Outlets of the company in the pipeline. ${ }^{\star *}$ Outlet bombed. 
In the case of MTN Nigeria, the telecommunication service provider has its head office in Lagos with regional offices in every region. It also maintains other customer relations' offices in almost all states of the federation. Based on the assessment of one of its regional managers in Oluyole, Ibadan, insecurity activities like militancy and insurgency have not directly affected their services as a result of the nature of their services. As a service providing company, virtually everybody subscribe to it including the militants and terrorists in their communication processes and strategies. He however said that some of their installations in the North-East were destroyed by Boko Haram explosives in 2012, 2013 and 2014 respectively which caused total cut-off of network services in some parts of the region and affected the quality of services in some other areas. Some of the customer relations outlets in those areas were also closed down indefinitely for safety of the staff. Overall, the profitability of the company has not been really affected on the average.

Nestle Nigeria PLC represents is a consumable multinational company with both its corporate head office and production factory in Industrial Avenue Ilupeju, Lagos. Its range of products includes food beverages, infant milk and cereals, confessionary, food seasonings and other household consumables. Speaking with a marketing manager in this company, she explained that the location of the industry's production factory in Lagos is a big plus for it. It has marketing officers and sale representatives in all state of the federation. Their jobs are more of building and sustain smooth relations with the wholesalers and retails in the chain of production. This relationship building, according to the respondent from the organisation is necessary because many of these middlemen (retailers, wholesalers) are also sellers of Nestle competitors' products. She however pointed out that, some of the major marketers in the troubled zone in the North suffered attacks when suicide bombers detonated in the markets and some departmental stores in the area. There were also occasion of theft where the insurgents looted shops and stores in the area. In such situations, she claimed the company only assisted some of these middlemen by giving them support fund to renovate their stores and gave them goods upfront to be able to recover from the effects of the attacks. Overall, the company has not suffered directly from insecurity.

Peugeot Automobile Nigeria PLC (PAN) has its headquarters in Kaduna and a service outlet in Lagos. The debut of this company in Nigeria in1971 was the result of effort of the Federal Government under the leadership of General Yakubu Gowon to establish an automobile manufacturing company in the country. Gowon initiated the idea in 1969 with a view to bringing about industrial revolution in Nigeria through partnership with the company. The memorandum of understanding was signed with Peugeot in 1971 out of 16 vehicle manufacturing companies that bided for the offer. The company was incorporated as a limited liability firm in December 1972. The primary mandate for the company was to begin assembling cars in Nigeria at its Kaduna plant, among other responsibilities. According to the respondent from this company, its operations have never 
been dictated by insecurity activities either from the Niger Delta or from the North-East. He said the assembling plant in Kaduna has not recorded any attack. Although, it shut down for a period of six years to reopen in August 2014, this he said was not at the instance of the insecurity in the north. He further explained that the closure was occasioned by internal technical and financial challenges confronting the company at the time. For those who need the services of the company, they go to the Lagos office located at PAN Drive, Victoria Island.

Julius Berger Nigeria PLC is a construction company representing the construction sector of FDI in this study. The headquarters of the German company is located at Utako District, Abuja. It has its main office at Ijora Causeway, Apapa Lagos and another office at Uyo, Akwa Ibom State. According to the respondent from this company, Julius Berger is a household name in Nigeria. Notable for all the gigantic building, roads and bridges constructed by the company in Nigeria, its operations in the country date back to decades. The operations of the company cut across the entire country including the Niger Delta and the North-East. Some of the personnel of the company have suffered attacks in the course of duty both in the Niger Delta and the North-East. The company recorded the kidnap of two expatriates in South-South and one death in the North. The kidnapped victims were released after payment of ransom. These unfortunate incidents according to the respondent have not affected the pattern of investment of the company in Nigeria.

In summary, the dynamism of insecurity reflected in the modes of operations which were becoming swifter and faster leading to more fatalities as the year progressed. While there were improvements in the lethargy of weapons from knives and machetes at their early stage to the use of guns like AK47, assault rifles, to detonations of Improvised Explosive by male and female suicide bombers. The weaponry was becoming more and more sophisticated as the year progressed, thus making the country to record more fatalities. The total number of fatalities from 1999 to 2014 was put at 37,046 with 2014 alone recording 11,529 out of the total number of fatalities. The patterns of investment on the other hand reflected a fluctuation as the year progressed within the period of study. It was a bit steady from 1999 to 2005 . Investment in the oil sector recorded a decrease of $20 \%$ between 2006 and 2008 due to the intensity of militant activities in the Niger Delta region at the time. There was also drop in oil production from 3.2 million barrels per day to $1.2 \mathrm{mbpd}$ as a result of the increase in militant activities like sabotage, oil bunkering, hostage takings and kidnapping. The number of reportedly kidnapped persons from 2006 to 2009 was 512. Towards the end of 2009, the oil sector recorded an upward swing and became steady afterwards up to 2011 recorded $2.31 \mathrm{mbpd}$ in production by 2012 but there was a decrease by the end of 2013 to 2.21. Overall, FDI has witnessed a continuous increase in non-oil sector like retail, real estate, automobile but these are concentrated at some regions considered as less-risky of attacks on investment. This reduced the potential benefits of the country from the sector. 


\section{Conclusion}

In the light of the above, the government of Nigeria must be proactive in addressing all issues of insecurity while the security agencies must make double efforts in combating security challenges confronting the country especially in the host communities so as to provide a conducive, less risky and safe business environment as emphasised by the liberal transnationalism theory. This is to enable the country to continue to attract investible capital, as well as allow for spread of investment across those areas considered as risky zones.

\section{Conflicts of Interest}

The author declares no conflicts of interest regarding the publication of this paper.

\section{References}

Blomberg, B., Hess, G., \& Orphanides, A. (2004). The Macroeconomic Consequences of Terrorism. Journal of Monetary Economics, 51, 1007-1032.

https://doi.org/10.1016/j.jmoneco.2004.04.001

Buckley, P. J., Clegg, J., Wang, C., \& Cross, A. R. (2002). FDI, Regional Differences and Economic Growth. Panel Data Evidence from China. Transnational Corporation, 11, $1-28$.

Chen, C. (1996). Regional Determinants of Foreign Direct Investment in Mainland China. Journal of Economic Studies, 23, 18-30. https://doi.org/10.1108/01443589610109649

Cheng, L. K., \& Kwan, Y. K. (2000). What Are the Determinants of Location of FDI? The Chinese Experience. Journal of International Economics, 51, 379-400. https://doi.org/10.1016/S0022-1996(99)00032-X

Coughlin, C. C., Terza, J., \& Arromdee, V. (1991). State Characteristics and the Location of Foreign Direct Investment within United States. Review of Economics and Statistics, 73, 675-683. https://doi.org/10.2307/2109406

Crain, N. V., \& Crain, W. M. (2006). Terrorised Economies. Public Choice, 128, 317-349. https://doi.org/10.1007/s11127-006-9056-6

Dunning, J. H. (1992). Multinational Enterprises and the Global Economy. Addison Wesley.

Enders, W., \& Sandler, T. (1993). Economic Impact of Terrorist Actions on Foreign Direct Investments: A Pooled Time-Series Analysis.

Enders, W., \& Sandler, T. (1996). Terrorism and Foreign Direct Investment in Spain and Greece. Kyklos, 49, 331-335. https://doi.org/10.1111/j.1467-6435.1996.tb01400.x

Friedman, J., Gerlowski, D. A., \& Silberman, J. (1992). What Attracts Foreign Multinational Corporations? Evidence from Plant Location in the United States. Journal of Regional Science, 32, 403-418. https://doi.org/10.1111/j.1467-9787.1992.tb00197.x

Global Terrorism Database (2014). Measuring the Impact of Terrorism in Nigeria.

Lim, E. (2001). Determinants of and Relationship between FDI and Growth: A Summary of Recent Literature. IMF Working Paper No. 175, International Monetary Fund. https://doi.org/10.5089/9781451858754.001

Marfleet, P. (2006). Refugees in a Global Era. Palgrave, Macmillan. 
Martins, G. (2007). Understanding Terrorism (2nd ed.). Sage.

Nye, J. S., \& Keohane, R. O. (1998). Power and Interdependence in the Information Age. Foreign Affairs, 77, 81-94. https://doi.org/10.2307/20049052

Viotti, P. R., \& Kauppi, M. V. (2012). International Relations Theory (5th ed.). Longman, Pearson.

Wagner, J. (2006). Exports, Foreign Direct Investment, and Productivity: Evidence from Germany Firm Level Data. Economic Papers, 13, 347-349. https://doi.org/10.1080/13504850500393667

Waltz, K. (1979). Theory of International Politics. Addison Wesley. 